\title{
Bulletin of the Atomic Scientists
}

\section{Holding fossil fuel companies accountable for their contribution to climate change: Where does the law stand?}

\section{Michael Burger \& Jessica Wentz}

To cite this article: Michael Burger \& Jessica Wentz (2018) Holding fossil fuel companies accountable for their contribution to climate change: Where does the law stand?, Bulletin of the Atomic Scientists, 74:6, 397-403, DOI: 10.1080/00963402.2018.1533217

To link to this article: https://doi.org/10.1080/00963402.2018.1533217

曲 Published online: 24 Oct 2018.

Submit your article to this journal $\llbracket$

Џ Article views: 12

View Crossmark data \ulcorner 


\title{
Holding fossil fuel companies accountable for their contribution to climate change: Where does the law stand?
}

\author{
Michael Burger and Jessica Wentz
}

\section{ABSTRACT}

The judge who called for a climate tutorial in a federal court in San Francisco accepted the science that says that human-caused emissions of carbon dioxide play the central role in rising average global temperatures, increased sea levels, and coastal flooding - but threw out a lawsuit calling for financial reparations from the oil companies for causing these problems. Why? And what might the decision mean for other cases in other states, along similar lines, that are still in the works? Two environmental lawyers, one of whom was in the courtroom for the tutorial, explain.

\section{KEYWORDS}

Climate change; climate reparations; climate tutorial; climate litigation; climate liability; fossil fuels; greenhouse gases
In the past year, state and local governments across the United States have launched a new wave of litigation seeking to hold fossil fuel companies liable for damages caused by climate change. To date, 13 cities and counties in California, Colorado, Washington, and New York have filed lawsuits against major oil and gas producers such as ExxonMobil, BP, Chevron, and Shell, and in July the state of Rhode Island initiated its own legal proceedings, suing over damages caused to its infrastructure and coastal communities by climate change - the first time a US state has done so. ${ }^{1}$ The basic argument underpinning these suits is that these companies knowingly contributed to climate change by extracting and selling fossil fuels, obscuring the science of climate change, and fighting policies aimed at mitigating climate change (Heede 2016) - and consequently they should therefore be held accountable for some of the adaptation costs incurred by governments. The plaintiffs are pursuing multiple state law legal theories: public nuisance, private nuisance, negligence, trespass, failure to warn, and design defect, among others.

These lawsuits raise interesting questions about causation and attribution of climate-related damages: Whether and to what extent can we legally attribute harmful impacts associated with climate change to specific actors or conduct?

There is no easy answer to this question. The field of climate change detection and attribution is rapidly evolving, and attribution studies are increasingly capable of linking specific harmful events - such as hurricanes and wildfires - to climate change (Shulman 2017). But establishing a complete causal chain in a court of law that links greenhouse gas emissions from fossil fuels extracted and sold by a particular company to specific damages is a more challenging task. Linking impacts to emitters is more challenging than linking impacts to anthropogenic climate change. Such attribution involves identifying, with relative confidence, the proportional contribution of the company's fossil fuels to changes in global atmospheric composition, extrapolating the proportional contribution to more localized impacts such as sea level rise, and then identifying actual damages (e.g., physical damage to infrastructure) that were caused by those impacts (as opposed to the negligence of other actors). Further complicating this inquiry is the fact that "responsibility" is not a purely scientific concept: Even if scientists can attribute specific damages to emissions from fossil fuels produced by a specific company, there are still questions about how responsibility should be allocated between the company that produced the fuels, the end users of those fuels (e.g., electric utility companies, people driving cars), and other actors involved in the fossil fuel supply and consumption chain.

Confronted with the complexities of climate science, the federal judge overseeing the cases brought by San Francisco and Oakland - William Alsup - scheduled a tutorial in which he asked both sides to present the history of climate science and "the best science now available on global warming, glacier melt, sea rise, and coastal flooding." Judge Alsup asked the parties to answer nine questions, such as "What are the main sources of heat that account for the incremental rise in temperature on Earth?" 


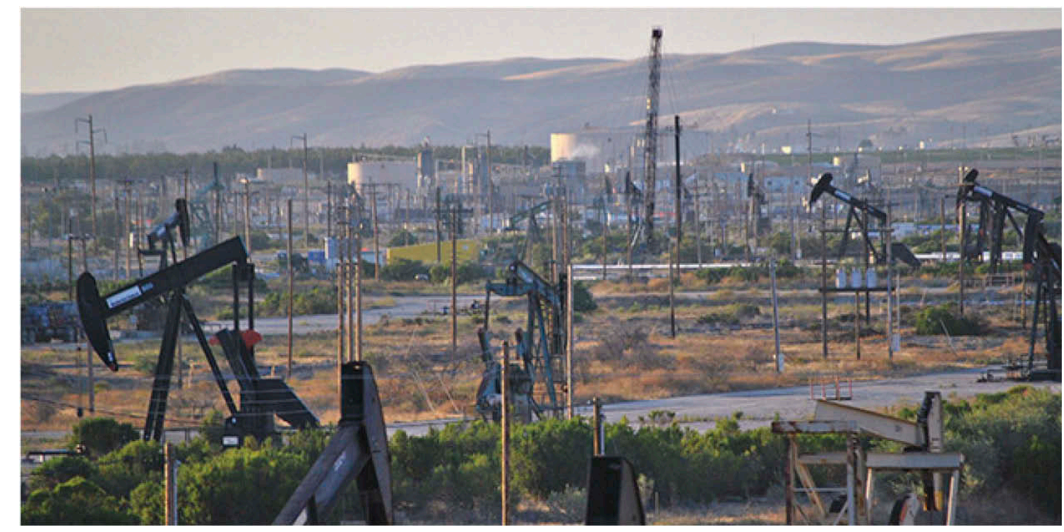

Figure 1. San ardo oil field in california, one of the state's largest. photo courtesy of loco steve/wikimedia under creative commons license. https://commons.wikimedia.org/wiki/file:The_san_ardo_oil_field_from_the_coast_starlight._(6132948846).jpg.

And during the tutorial, the attorney for the oil giant Chevron conceded that fossil fuel consumption contributes to climate change and made the memorable statement that: "Chevron accepts the consensus in the scientific communities on climate change... There's no debate about climate science."

Nonetheless, the attorney for Chevron insisted that fossil fuel companies should not be held responsible for harms associated with climate change. Had the case proceeded to trial, the parties would have had an opportunity to dive much deeper into the scientific basis for attributing climate-related harms to these companies. But Judge Alsup dismissed the case before it went to trial on grounds wholly unrelated to the climate science.

The Verge summed it up in the headline: "Oil companies can't be sued for climate change even though it's real, judge rules." (Becker 2018)

Why this result?

Judge Alsup's primary rationale for dismissal was that the courts are not the proper place to deal with such global issues as determining rights and assigning responsibility for the damages caused by fossil fuel use. Rather, Judge Alsup believed that such matters should be addressed by the executive and legislative (otherwise known as the "political") branches of government and not the judiciary. The case brought by New York City has since been dismissed on the same grounds.

Notably, neither decision is binding on other courts, and the cities have either appealed or announced plans to appeal. So it is possible that other government plaintiffs will succeed and these initial decisions will be reversed. Certainly, plaintiffs face an uphill battle: Past attempts to hold fossil fuel companies liable for these types of harms have all failed. But these new cases pursue different legal theories and involve claims that may not be controlled by any existing case precedent, so it is possible that at least some will succeed.
Below we discuss the prospects for this new line of cases, and in particular, whether other judges might also conclude that the courts are not the appropriate forums for addressing these issues.

\section{What's past is prologue: The federal cases that failed}

This is not the first time that state and local governments have sought to hold companies that profit from the sale and consumption of fossil fuels liable for their contributions to climate change. There are two noteworthy cases which set the stage for this new wave of litigation: Connecticut v. American Electric Power (AEP) and Kivalina v. ExxonMobil. The first was a lawsuit brought by eight states and New York City against several major power companies, seeking an injunction which would require those companies to reduce their greenhouse gas emissions. The second was a lawsuit brought by the Alaskan village of Kivalina against major fossil fuel and power companies, seeking monetary damages for flooding caused by climate change. The plaintiffs in both cases alleged that the emissions generated by the defendants' conduct constituted a public nuisance under federal common law. (The complaints in both cases also raised state law claims, but they were never decided.)

The phrase "common law" refers to the legal standards and principles articulated through judicial decisions, as opposed to statutes and regulations. A "public nuisance" is a common law wrongful act, or "tort," defined as "an unreasonable interference with a right common to the general public." For many years, courts have recognized that water pollution, air pollution, and other environmental harms may qualify as public nuisances. The factors courts will consider in this analysis 
are: (a) whether the conduct involves a significant interference with the public's health, safety, peace, comfort or convenience; (b) whether the conduct is proscribed by law; or (c) whether the conduct is of a continuing nature or has produced a permanent or long-lasting effect, and, as the actor knows or has reason to know, has a significant effect upon the public right to health, safety, peace, comfort or convenience.

Both AEP and Kivalina were ultimately dismissed based on the doctrine of "legislative displacement," which bars the application of federal common law when a federal statute directly addresses the question at issue. The basic idea is that judge-made laws should only be used to fill gaps in the legal regimes established by the political branches of government. Regarding the public nuisance claim in $A E P$, the Supreme Court held that plaintiffs could not pursue a public nuisance claim against emitters under federal common law because Congress had already authorized the Environmental Protection Agency to regulate those emissions under the Clean Air Act. The Kivalina case was subsequently dismissed by the 9th Circuit Court of Appeals on the same grounds.

AEP and Kivalina effectively foreclosed opportunities to use the federal common law as the basis for suing emitters of greenhouse gases in the United States. Recognizing this, the plaintiffs in this new line of cases are attempting to use state common law as the basis for their claims. But as discussed below, some of the cases - including the Bay Area and New York City cases have been converted into federal cases on the grounds that claims of a global scope should be governed by federal law. These will likely fare worse than those that are decided under state law.

\section{The new wave of climate liability lawsuits}

On 17 July 2017, three local governments in California (San Mateo County, Marin County, and the city of Imperial Beach) filed lawsuits against 20 fossil fuel companies seeking to hold them liable for climate change-related damages under California state law. The factual and legal allegations in these complaints differ in some respects from those raised in $A E P$ and Kivalina. In particular, the plaintiffs alleged that these companies had committed multiple state common law violations, including: public nuisance - an unreasonable interference with a right common to the public; private nuisance - an unreasonable interference with the use and enjoyment of private property (or in this case, the municipal property owned and managed by the plaintiffs); negligence - the failure to exercise due care, resulting in damage or injury to another party; design defect - a problem with a product's design that makes it inherently dangerous or useless (in this case, the fossil fuels are the product and the emissions impacts are the defect); failure to warn - the failure to provide adequate warning of a product defect; and trespass - a knowing physical intrusion onto another person's property.

The plaintiffs alleged that the conduct giving rise to these violations was not only the production and marketing of fossil fuels (and their corresponding emissions impacts), but also the fact that these companies knew that their product was harmful, continued to promote it anyway, and engaged in a prolonged disinformation campaign aimed at confusing the public and preventing regulators from taking action to control fossil fuel use.

Since then, similar lawsuits have been filed by the cities of San Francisco, Oakland, Richmond, and Santa Cruz; the county of Santa Cruz; New York City; the city of Boulder, the county of Boulder, and the county of San Miguel in Colorado; King County in Washington; Baltimore; and the state of Rhode Island. All of the government plaintiffs have framed their cases as involving violations of state tort law, but the fossil fuel company defendants have argued that the cases implicate federal law and have been fighting to have the cases removed to federal court and considered under federal legal doctrines - where they believe they stand a better chance of victory - and dismissed.

While the cases involve similar factual allegations, one important distinction is that the lawsuits brought by San Francisco and Oakland rested exclusively on a theory of public nuisance, whereas the other lawsuits rely on some combination of the legal theories noted above as well as some other theories (the Colorado communities are alleging unjust enrichment and violations of the Colorado Consumer Protection Act, and Rhode Island is alleging impairment of public trust resources and a violation of the State Environmental Rights Act).

The lawsuits brought by San Francisco and Oakland were consolidated and successfully removed to federal court by the defendants. The federal judge overseeing the case (William Alsup, as noted above) held that the plaintiffs' public nuisance claims were "necessarily governed by federal law" because a "uniform standard of decision is necessary to deal with the issues raised in plaintiffs' complaint." Notably, another federal judge the one overseeing the case brought by the counties of Marin and San Mateo and the city of Imperial Beach reached the opposite conclusion and remanded the cases back to state court. Aspects of that decision are now being appealed. 
In June, Judge Alsup granted the defendants' motion to dismiss the re-branded federal public nuisance claims brought by San Francisco and Oakland, along with the state law claims. As noted above, his decision is not controlling on other courts but may provide some insight into how other judges might decide these issues.

Judge Alsup brought attention to the case when he asked the parties to participate in the "climate science tutorial" aimed at educating him about the scientific underpinnings of climate change. But as previously noted, the science discussion had little impact on the decision; Judge Alsup stated in the first sentence of his analysis that " $t]$ he issue is not over science." Rather, the issue - in his opinion - was about precedent, and the separation of powers between Congress, the White House, and the judiciary.

One threshold question was whether the controlling rule in AEP and Kivalina - that federal common law claims of public nuisance based on greenhouse gas emissions were displaced by the Clean Air Act's grant of authority to EPA to regulate those emissions would also control the outcome of these cases. Judge Alsup determined it did, at least to the extent that the complained - of behavior occurred within the United States, because ultimately the harms were caused by greenhouse gas emissions. However, Judge Alsup also noted that the complaints added a dimension that was not addressed in AEP or Kivalina - specifically, that some of the conduct and emissions contributing to the alleged nuisance occurred outside of the United States and thus could not be regulated under the Clean Air Act. Here, Judge Alsup held that the claims were "foreclosed by the need for federal courts to defer to the legislative and executive branches when it comes to such international problems" as climate change. He concluded that:

This order fully accepts the vast scientific consensus that the combustion of fossil fuels has materially increased atmospheric carbon dioxide levels, which has in turn increased the median temperature of the planet and accelerated sea level rise. But questions of how to appropriately balance these worldwide negatives against the worldwide positives of the energy itself, and how to allocate the pluses and minuses among the nations of the world, demand the expertise of our environmental agencies, our diplomats, our Executive, and at least the Senate. Nuisance suits in various United States judicial districts regarding conduct worldwide are far less likely to solve the problem and, indeed, could interfere with reaching a worldwide consensus.

Judge Alsup thus dismissed the case based on separation of powers principles. He did not, however, explicitly address two judicial doctrines that are commonly used by courts to determine whether adjudication of claims would violate the separation of powers: the political question doctrine and foreign affairs preemption. San Francisco has stated its intent to appeal the decision (Schwartz 2018).

The following month, a district judge in New York, John F. Keenan, dismissed the lawsuit brought by New York City on the same grounds. Judge Keenan issued a single decision holding that the claims raised by New York City were governed by federal common law, that the claims alleging harms from domestic emissions were displaced by the Clean Air Act, and that the claims alleging harms from defendants' foreign conduct would interfere with the separation of powers, particularly the foreign policy powers of other branches. (More on these doctrines is below.) Like Judge Alsup, Judge Keenan did not specifically evaluate foreign affairs preemption or the political question doctrines before reaching his conclusion that the separation of powers doctrine barred review of this case. New York City plans to appeal the decision (Drugmand 2018).

Both Judge Alsup and Judge Keenan decided not to address these doctrines. But the doctrines could still be considered relevant to the cases. For example, the analysis in both decisions directly implicated questions that are often resolved through application of specific criteria embedded within these two doctrines. We discuss these further in the next section.

\section{Future prospects for government plaintiffs}

There are several reasons to think that other judges including the appellate judges that review the two decisions dismissing these cases - may take a different stance on whether the separation of powers doctrine bars judicial review of federal public nuisance claims, as well as state tort claims. To understand why, one should analyze the case applying the criteria used by the federal courts for political questions or foreign affairs preemption. One can also look to differences in state law treatment of the separation of powers doctrine to understand why cases that are allowed to remain in state court might be decided differently.

The political question doctrine is commonly used to determine whether the court system is an appropriate forum for adjudicating a particular federal claim in light of the separation of powers principles. The Supreme Court has identified specific factors for determining whether a plaintiff has presented a political question best left to the other branches - such as whether there are judicially manageable standards for 
resolving the case, and whether judicial resolution of the case would disrespect the other branches of government. The Supreme Court has noted that unless one of those factors is clearly implicated, there should be no dismissal on political question grounds.

Notably, before the AEP case was dismissed by the Supreme Court due to legislative displacement, the Second Circuit Court of Appeals specifically applied these factors to the plaintiff's nuisance claim and concluded that it was not a political question. The court noted that "federal courts have successfully adjudicated complex common law public nuisance cases for over a century" and cited many examples of cases where "federal courts employed familiar public nuisance precepts, grappled with complex scientific evidence, and resolved the issues presented, based on a fully developed record." The court thus concluded that $A E P$ was an "ordinary tort suit" that could be adjudicated based on well-established common law standards.

The Second Circuit Court of Appeals also found that there was no "unified policy on greenhouse gas emissions" and that "[a]llowing this litigation where there is a lack of a unified policy does not demonstrate a lack of respect for the political branches, contravene a relevant political decision already made, or result in multifarious pronouncements that would embarrass the nation."

On review, the Supreme Court did not think the political question doctrine "or any other threshold obstacle" barred judicial review of the case. The Second Circuit's analysis of the political question doctrine was therefore left in place and may prove persuasive to other judges reviewing this new line of cases.

The other doctrine that could be used to evaluate defendants' separation of powers arguments - foreign affairs preemption or displacement - is typically used by courts to evaluate whether a state or local law is preempted by the constitutional commitment of foreign affairs powers to the federal government. The doctrine is relevant to the municipal lawsuits insofar as the separation of powers arguments raised by defendants in their motions to dismiss are largely based on assertions that judicial resolution of these cases would impermissibly interfere with the foreign affairs powers of the executive and legislative branches.

The standards for foreign affairs preemption have never been articulated that clearly, but the Supreme Court has provided some guidance on how to determine whether a particular law is preempted under this doctrine. In particular, the Court has held that a state law is preempted where there is a "clear conflict" with US foreign policy, as articulated in executive agreements, treaties, or statutes. Such a conflict would exist "where it is impossible for a private party to comply" with both state law and federal law on a particular foreign affairs matter. A law may also be preempted if it authorizes or requires entities other than Congress and the president to engage in the conduct of foreign policy or otherwise impairs the federal government's ability to conduct foreign policy. These preemption rulings have all been issued in the context of state statutes, but similar principles could be applied to displace common law actions as well (Merrill 2005).

There is some overlap between the foreign affairs preemption/displacement analysis and the political question analysis - for both inquiries, a court must address whether judicial resolution of the case would interfere with the execution of core foreign policy functions of other branches of government. Recognizing this, the Second Circuit in AEP confronted and quickly dismissed a foreign affairs displacement claim, noting that " $[\mathrm{t}]$ his argument - essentially that plaintiff's federal common law cause of action has been displaced by the president's conduct of foreign affairs - simply reiterates their political question argument and must be rejected for similar reasons" (Connecticut v. Am. Elec. Power Co 2011).

The decisions to dismiss the lawsuits brought by San Francisco, Oakland, and New York largely rested on the judges' belief that adjudication would violate the delegation of foreign affairs powers to other branches of government, although as noted above, neither judge explicitly discussed this doctrine or the underlying case law. Other reviewing courts may likewise focus on considerations pertaining to foreign policy. It is difficult to predict what outcomes they will reach. A court might take the same approach as the Second Circuit in $A E P$ and conclude that judicial resolution of these claims would not conflict with US foreign policy because there is no coherent or unified US foreign policy on climate change. (On the one hand, we are parties to both the United Nations Framework Convention on Climate Change (UNFCCC) and the Paris Agreement; on the other hand, President Trump has stated his intention to withdraw from the Paris Agreement and is otherwise working to undermine the objectives of the UNFCCC). Alternatively, a court might conclude that the Senate ratification of the UNFCCC is a sufficiently coherent articulation of US foreign policy on climate change but that the adjudication of these disputes does not conflict with that policy or impair the ability of our federal government to participate in UNFCCC negotiations. (A court might even find that holding those companies liable for emissions could advance the goals of the UNFCCC and improve the US position in UNFCCC negotiations.) 
A court could also reach the opposite conclusion, finding that the claims cannot be heard by a federal court either because they directly conflict with the Trump administration's foreign policy on climate change (as embodied by the decision to withdraw from the Paris Agreement and roll back federal emission standards) or would undermine the federal government's position in UNFCCC negotiations.

\section{What does the future hold?}

So far, we have focused on how other federal judges deciding these cases under federal law might approach the separation of powers analysis. Some cases, such as the lawsuits brought by Marin and San Mateo and the city of Imperial Beach, appear likely to stay in state court and be decided under state law. Separation of powers principles play out differently under state law. Consider the example of California: The state courts have developed their own separation of powers jurisprudence based on the state constitution, which holds that a violation of the doctrine only occurs when the actions of one branch of government "defeat or materially impair" the core powers or functions of another branch. Under this standard, it is permissible for one branch of government to undertake actions that "significantly affect those [actions] of another branch" so long as the acting branch does not prevent other branches from exercising core functions delegated to them by the state constitution. There is room to argue that the adjudication of the legal claims raised against fossil fuel companies - and the potential for a verdict holding fossil fuel companies liable for costs associated with climate change - would not materially impair the ability of the state legislative and executive branches to execute their own lawmaking and regulatory functions with respect to climate change. To the contrary, a judge might conclude that such judicial action would complement and supplement the programs enacted by other branches of the state government.

If judges determine that the separation of powers doctrine and related considerations do not bar adjudication of these cases, the plaintiffs will still face challenges - such as arguments that federal statutes establishing domestic energy policy and authorizing fossil fuel production preempt common law claims, and the challenge of linking the conduct of fossil fuel companies to specific on-the-ground impacts that are harming the plaintiffs. In the latter context, scientific questions, particularly those pertaining to climate change attribution, will become far more important. But at this preliminary stage, the focus is on prudential and political rather than scientific considerations, in particular, whether courts are the appropriate branch of government to determine rights and assign responsibilities for the damages caused by fossil fuels.

\section{Note}

1. City of Imperial Beach v. Chevron Corp. (2017); City of Oakland v. BP P.L.C. (2017); City of Santa Cruz v. Chevron Corp. (2017); County of Marin v. Chevron Corp. (2017); County of San Mateo v. Chevron Corp. (2017); County of Santa Cruz v. Chevron Corp. (2017); People of the State of California v. BP P.L.C. (2017a); People of the State of California v. BP P.L.C. (2017b); City of Richmond v. Chevron Corp. (2018); Board of County Commissioners of Boulder County v. Suncor Energy (2018); City of New York v. BP P.L.C. (2018); State of Rhode Island v. Chevron (2018).

\section{Disclosure statement}

No potential conflict of interest was reported by the authors.

\section{Funding}

This research received no specific grant from any funding agency in the public, commercial, or not-for-profit sectors.

\section{Notes on contributors}

Michael Burger is the executive director of the Sabin Center for Climate Change Law, and a research scholar at Columbia Law School.

Jessica Wentz is a senior fellow at the Sabin Center for Climate Change Law and an associate research scholar at Columbia Law School.

\section{References}

Becker, R. 2018. “Oil Companies Can't Be Sued for Climate Change Even though It's Real, Judge Rules: 'The Issue Is Not over Science,' Judge Alsup Wrote." The Verge. June 26. https://www.theverge.com/2018/6/26/17507620/cli mate-lawsuits-san-francisco-oakland-sue-big-oil-judgealsup-chevron-exxon

Board of County Commissioners of Boulder County v. Suncor Energy (U.S.A.), Inc. 2018. No. 2018CV030349 (Colo. Dist. Ct. filed 4/17/18).

City of Imperial Beach v. Chevron Corp. 2017. No. C1701227 (Cal. Super Ct. filed 7/17/17).

City of New York v. BP P.L.C. 2018. No. 1:18-cv-00182. No. (S.D.N.Y. filed 1/9/18). 
City of Oakland v. BP P.L.C. 2017. No. 3:17-cv-06011, No. (N.D. Cal. filed 10/20/17).

City of Richmond v. Chevron Corp. 2018. No. C18-00055 (Cal. Super. Ct. filed 1/22/18).

City of Santa Cruz v. Chevron Corp. 2017. No. 17CV03243 (Cal. Super. Ct. filed 12/20/17).

Connecticut v. Am. Elec. Power Co. 2011. 582 F.3d 309, 388 (2d Cir. 2009), rev'd, 564 U.S. 410.

County of Marin v. Chevron Corp. 2017. No. C17-02586 (Cal. Super. Ct. filed 7/17/17).

County of San Mateo v. Chevron Corp. 2017. No. C17-03222 (Cal. Super. Ct. filed 7/17/17).

County of Santa Cruz v. Chevron Corp. 2017. No. 17CV03242 (Cal. Super Ct. filed 12/20/17).

Drugmand, D. 2018. "New York City Suit Dismissed by Federal Judge." Climate Liability News, July 19. https:// www.climateliabilitynews.org/2018/07/19/new-york-cityclimate-suit-john-keenan/

Heede, R. 2016. "Just 90 Companies are Accountable for More than 60 Percent of Greenhouse Gases." Bulletin of the Atomic Scientists, October 27. https://thebulletin.org/ 2016/10/just-90-companies-are-accountable-for-morethan-60-percent-of-greenhouse-gases/

Merrill, T. W. 2005. "Global Warming as a Public Nuisance." 30. Columbia Journal of Environmental Law 293. https:// scholarship.law.columbia.edu/faculty_scholarship/2154

People of the State of California v. BP P.L.C. 2017a. No. CGC-17-561370 (Cal. Super. Ct. filed 9/19/17).

People of the State of California v. BP P.L.C. 2017b. No. RG17875889 (Cal. Super. Ct. filed 9/19/17).

Schwartz, J. 2018. "Judge Throws Out New York Climate Lawsuit." New York Times, July 19. https://www. nytimes.com/2018/07/19/climate/climate-lawsuit-newyork.html.

Shulman, S. 2017. "Suing Oil Companies to Pay for Climate Change?" Bulletin of the Atomic Scientists, October 5. https://thebulletin.org/2017/10/suing-oil-companies-topay-for-climate-change/

State of Rhode Island v. Chevron. 2018. No. PC-2018-4716 (Rhode Island Super. Ct. filed 7/2/18). 